\title{
Micromorphology of trichomes and composition of essential oil of Teucrium capitatum
}

\author{
Teresa Antunes, ${ }^{1}$ Isabel Sevinate-Pinto, ${ }^{1}$ José G. Barroso, ${ }^{2}$ Carlos Cavaleiro ${ }^{3}$ and \\ Lígia R. Salgueiro ${ }^{3 *}$ \\ ${ }^{1}$ Centro de Biologia Ambiental, Departamento de Biologia Vegetal, Faculdade de Ciências de Lisboa, C2 Campo Grande 1749- \\ 016, Lisboa, Portugal \\ ${ }^{2}$ Centro de Biotecnologia Vegetal, Departamento de Biologia Vegetal, Faculdade de Ciências de Lisboa, C2 Campo Grande \\ 1749-016, Lisboa, Portugal \\ ${ }^{3}$ Laboratório de Farmacognosia/CEF, Faculdade de Farmácia, Universidade de Coimbra, Rua do Norte, 3000-295 Coimbra, \\ Portugal
}

Received 22 October 2002; Revised 10 April 2003; Accepted 21 April 2003

\begin{abstract}
The morphology and distribution of the glandular trichomes of Teucrium capitatum L., as well as the chemical composition of the essential oils, were studied. Important differences were found with regard to the major constituents of the essential oils of five populations of $T$. capitatum grown in Portugal. The oil isolated from one population was characterized by a high content of oxygenated monoterpenes $(33.0 \%)$, isomenthone $(\mathbf{7 . 7 \%})$ being the major constituent. Another oil from a population collected from the same region was dominated by monoterpene and sesquiterpene hydrocarbons $(43.9 \%$ and $23.2 \%$, respectively), $\alpha$-pinene $(7.7 \%)$, sabinene $(11.2 \%)$ and $\beta$-pinene $(10.3 \%)$ being the main compounds. The oils from the other three populations were characterized by a high content of both sesquiterpene hydrocarbons $(23.0 \%, 32.2 \%$ and $33.2 \%)$ and oxygenated sesquiterpenes $(39.7 \%, 23.4 \%$ and $20.4 \%)$. T-cadinol $(24.1 \%)$ and $\alpha$-cadinol $(\mathbf{9 . 8 \%})$ were the major compounds in the oil from one population, whereas $\delta$-cadinene $(7.5 \%$ and $9.8 \%)$ and $E$-caryophyllene $(5.4 \%)$ or $\alpha$-muurolol $(6.0 \%)$ were the major constituents in the other samples. The indumentum of the vegetative and reproductive ograns from the five populations of $T$. capitatum, observed under scanning electron microscopy, showed the same type and distribution of glandular and non-glandular trichomes. Since the ecological and edaphic features of the collecting sites were quite similar, the chemical polymorphism observed seems to be due to genetic factors. Copyright (C) 2004 John Wiley \& Sons, Ltd.
\end{abstract}

KEY WORDS: Teucrium capitatum; trichomes; histochemistry; essential oils; GC; GC-MS

\section{Introduction}

The section Polium, which includes Teucrium capitatum L. [= T. polium L. ssp. capitatum (L.) Arcangeli], contains more than half of the Teucrium spp. and is the largest and most morphologically diverse section of the genus. ${ }^{1,2}$ Teucrium capitatum, family Lamiaceae, is a Mediterranean dwarf shrub up to $45 \mathrm{~cm}$ tall, that grows wild in central and south-east Portugal. As in other Lamiaceae described in the literature, the aerial organs of Teucrium spp. are covered by an indumentum of glandular and non-glandular trichomes.

Some work on the composition of the volatile oils of Teucrium polium s.l. (subspecies not referred) were reported in the literature, ${ }^{3-6}$ and some chemical differences, probably related to the different subspecies and/ or to the geographical origin of the plants, were also

\footnotetext{
* Correspondence to: L. R. Salgueiro, Laboratório de Farmacognosia/CEF, Faculdade de Farmácia, Universidade de Coimbra, Rua do Norte, 3000-295 Coimbra, Portugal.

E-mail: ligia@ff.uc.pt
}

described. As far as we know, only one single study on the essential oil from $T$. polium mentions the subspecies (T. polium subsp. capitatum $=T$. capitatum $).{ }^{7}$ Thus, continuing our research on the micromorphology of trichomes and on the composition of the essential oils of the Portuguese Teucrium taxa, we now report on the results obtained with Teucrium capitatum L. The purpose of this work is to investigate the composition and chemical polymorphism of the essential oil from this species, as well as the micromorphology and histochemistry of the trichomes occurring on the leaves and flowers.

\section{Materials and Methods}

\section{Plant Material}

Aerial parts of the plants were collected at the flowering stage in June 1999 and 2000, in the centre of Portugal: Fonte Coberta; Serra do Sicó (sample 1); Rabaçal, Serra do Sicó (sample 2); Portunhos, Cantanhede (samples 3 and 4); and Covão do Feto, Serra D'Aire (sample 5). All 
the collecting sites are on limestone (calcareous). Voucher specimens were deposited in the Herbarium of the Botanical Institute of the University of Coimbra (COI).

\section{Scanning Electron Microscopy}

For scanning electron microscopy SEM, specimens from different plant parts were fixed for $3 \mathrm{~h}$ in a solution containing $3 \%$ glutaraldehyde in $0.1 \mathrm{M}$ cacodylate buffer (pH 7.1). The specimens were subsequently dehydrated in a graded ethanol series and dried by the critical point drying method, using a Polaron E 3500. The dried specimens were sputter-coated with gold in a Polaron E 5350, and then observed on a JEOL JSM T220 scanning electron microscope at $10 \mathrm{kV}$.

\section{Histochemistry}

The histochemical tests were carried out using fresh plant material. Total lipids were detected using Sudan Black ${ }^{8}$ and Nile blue A. ${ }^{9}$ The controls were tested simultaneously. The autofluorescence of secreted material was studied using a light epifluorescence microscope.

\section{Essential Oil Analysis}

The essential oil content of the air-dried plant material was determined according to the European Pharmacopoeia method. ${ }^{10}$ Analysis of volatile oils obtained by water distillation for $3 \mathrm{~h}$ were carried out by $\mathrm{GC}$ and GC-MS, using fused silica capillary columns with two different stationary phases: SPB-1 (polydimethylsiloxane, $30 \mathrm{~m} \times 0.20 \mathrm{~mm}$ i.d., film thickness $0.20 \mu \mathrm{m}$ ), and Supelco Wax 10 (polyethyleneglycol, $30 \mathrm{~m} \times 0.20 \mathrm{~mm}$ i.d., film thickness $0.20 \mu \mathrm{m})$; oven temperature programme, $70{ }^{\circ} \mathrm{C}$ to $220{ }^{\circ} \mathrm{C}$ (at $3{ }^{\circ} \mathrm{C} / \mathrm{min}$ ), $220^{\circ} \mathrm{C}(15 \mathrm{~min}$ ); injector temperature, $250{ }^{\circ} \mathrm{C}$; carrier gas, helium, adjusted to a linear velocity of $30 \mathrm{~m} / \mathrm{s}$; split ratio, 1:40; detector temperature, $250{ }^{\circ} \mathrm{C}$.

GC-MS was performed with a HP1 fused silica column (polydimethylsiloxane $30 \mathrm{~m} \times 0.25 \mathrm{~mm}$ i.d., film thickness $0.25 \mu \mathrm{m})$, interfaced with a mass selective detector. GC parameters were as above; interface temperature, $250{ }^{\circ} \mathrm{C}$; MS source temperature, $230{ }^{\circ} \mathrm{C}$; MS quadrupole temperature, $150^{\circ} \mathrm{C}$; ionization energy, $70 \mathrm{eV}$; ionization current, $60 \mu \mathrm{A}$; scan range, 35-350 u; scans/s, 4.51.

The identity of the components was achieved from their retention indices, calculated by linear interpolation relative to retention times of a series of $n$-alkanes, and their mass spectra, which were compared with those from our own library and from literature data. ${ }^{11,12}$
Relative amounts of individual components were calculated, based on GC peak areas without FID response factor correction.

\section{Results and Discussion}

Leaf, calyx and corolla specimens from the five populations of $T$. capitatum were studied using SEM. As in other Teucrium spp. ${ }^{13-15}$ vegetative and reproductive organs are covered by a very dense indumentum. The leaves showed the revolute form characteristic of the section Polium, to which this species belongs. The pluricellular non-glandular trichomes with an arborescent form, observed on the leaves (Figures 1, 2 and 3) and the calyx (Figure 7), make the observation of the glandular trichomes more difficult. Non-glandular trichomes with a similar shape were also observed on $T$. heterophyllum, an endemic species from Madeira. ${ }^{14}$ This type of trichome is found in only $16 \%$ of the 127 genera of the Lamiaceae studied. ${ }^{16}$ In contrast, the corolla indumentum (Figure 8) showed unbranched non-glandular trichomes, mainly located on the upper part of the adaxial surface.

Only transverse sections of the organs under study allowed up to recognise capitate and peltate glandular trichomes similar to those already reported for Teucrium species. ${ }^{17,18}$ The capitate trichomes possess one basal epidermal cell, two stalk cells and a glandular head cell (Figures 4 and 5), whereas the peltate ones are composed of a basal epidermal cell, a very short stalk cell and a multicellular head (Figure 6).

We did not recognize any particular pattern in the morphology and distribution of non-glandular and glandular trichomes in the five populations studied.

The capitate trichomes are uniformly distributed on the abaxial and adaxial surfaces of the leaves, while the peltate ones occur only on the abaxial surface (Figure 2). It is within the peltate glands that most of the essential oil is believed to be synthesized. ${ }^{19}$ The calyx indumentum of the abaxial side (Figure 7) is very similar to that of the leaves.

At the abaxial surface of the corolla, the glandular trichomes, capitate and peltate, are observed (Figure 8), the peltates being more abundant.

The apical cell of a capitate trichome shows a protuberance that corresponds to an elevation of the cuticle, formed by the secreted material accumulated in the subcuticular space. The content of this protuberance stains with Nile Blue (Figure 4A) and Sudan black, revealing the lipophilic nature of the secreted material. Similarly to $T$. salviastrum, ${ }^{18}$ the apical cell of capitate trichomes from $T$. capitatum assumes a cup-shape after the secretion release (Figure 5). Based on studies carried out with Salvia blepharophylla, BISIO et al. ${ }^{20}$ suggested two possible methods of release of secreted material: 

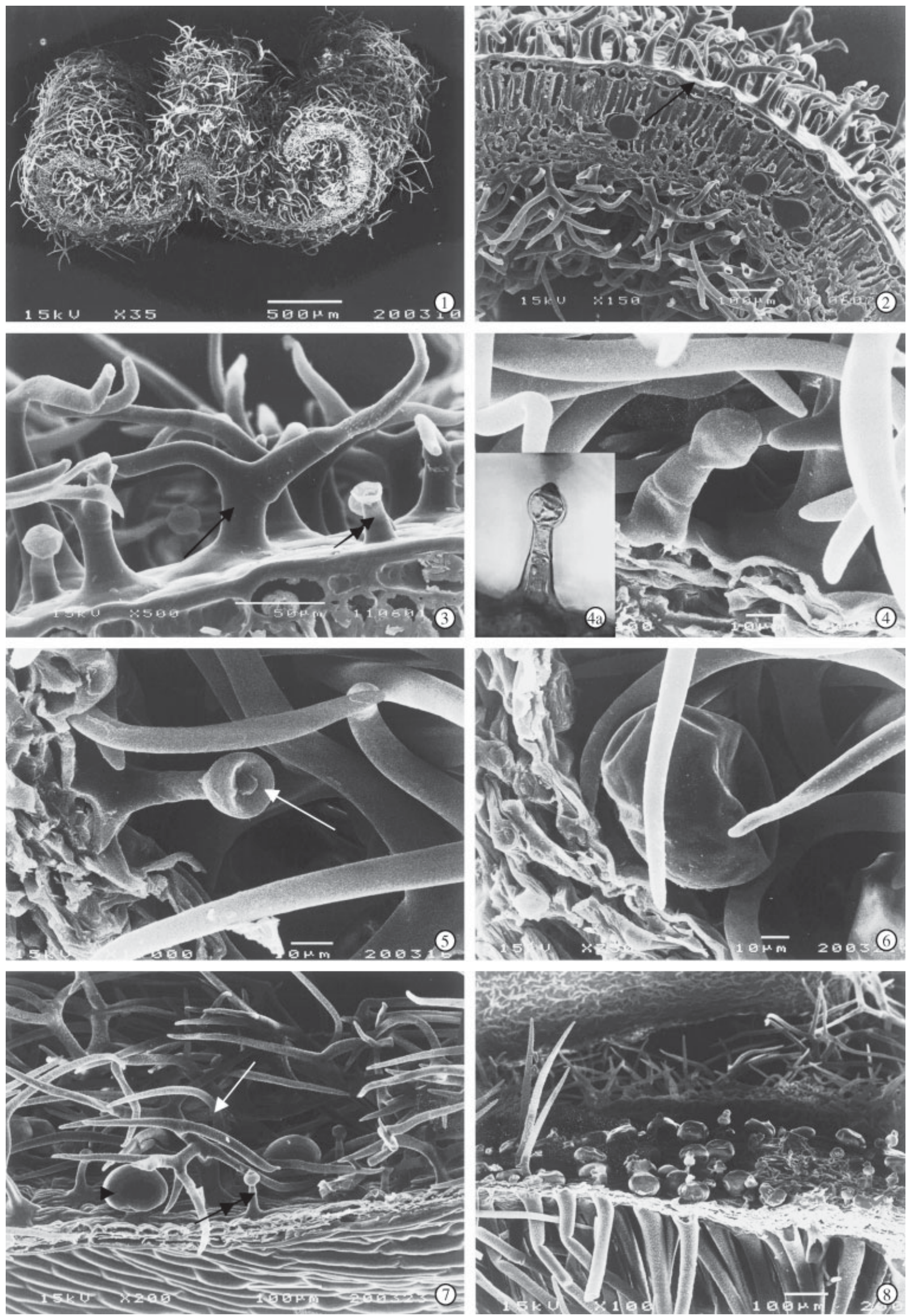
(a) breakage of the cuticle; or (b) via pores in the cuticle. As we could not observe any cuticle rupture on either peltate or capitate trichomes, it seems plausible that the secretion release via cuticle pores may operate in the glandular trichomes of $T$. capitatum.

The volatile oils of the air-dried aerial plant material were obtained with an average yield of $0.15(\mathrm{v} / \mathrm{w})$. In total, 103 compounds were identified in the five samples, which are listed in Table 1 in order of their elution on a polydimethylsiloxane column. Some important differences were found regarding the main constituents of the oils. One sample form Rabaçal, Serra do Sicó (sample 1) was characterized by a high content of oxygen-containing monoterpenes $(33.0 \%)$, isomenthone $(7.7 \%)$ being the main compound. This constituent, as well as menthol $(2.1 \%)$ and pulegone $(1.4 \%)$, were not detected in any of other four samples. The oil isolated from the other sample collected from the same region (Serra do Sicó: sample 2), was dominated by monoterpene and sesquiterpene hydrocarbons $(43.9 \%$ and $23.2 \%$, respectively), $\alpha$-pinene (7.7\%), sabinene (11.2\%) and $\beta$-pinene $(10.3 \%)$ being the main compounds. In contrast, the oils from the two samples collected at Portunhos (samples 3 and 4), and the sample from Serra D'Aire (sample 5), were characterized by high contents of both sesquiterpene hydrocarbons $(23.0 \%, 32.2 \%$ and $33.2 \%$, respectively) and oxygen-containing sesquiterpenes $(39.7 \%, 23.4 \%$ and $20.4 \%$, respectively). T-cadinol $(24.1 \%)$ and $\alpha$-cadinol $(9.8 \%)$ were the major constituents of the oil from sample $3 ; \delta$-cadinene $(7.5 \%)$ and $E$-caryophyllene $(5.4 \%)$ the major components in sample 4 ; and $\delta$-cadinene $(9.8 \%)$ and $\alpha$-muurolol $(6.0 \%)$ the main constituents in sample 5 .

Figures 1-8. Scanning electron micrographs of the leaf and flower surfaces of Teucrium capitatum. (1) Transverse leaf section showing its revolute margins and a dense indumentum. The glandular trichomes are obscured by the density of the non-glandular ones. (2) Transverse leaf section showing a very dense cuticle (arrow) and very abundant branched trichomes covering both the abaxial and adaxial surfaces. (3) Detail of Figure 2. Showing both non-glandular (arrow) and two capitate glandular trichomes (double arrow). (4) Aspect of a capitate trichome, observed in the middle of branched non-glandular trichomes. (a: Inset). The secreted material located in the subcuticular space reacts positively to Nile blue reagent. (5) Detail of a capitate trichome, showing a depression on the apical cell (arrow). (6) Detail of the abaxial leaf surface, showing a peltate trichome intermingled with non-glandular ones. (7) Transverse section of a sepal. The indumentum of the abaxial surface is similar to that observed on the leaves; non-glandular (arrows), capitate (double arrows) and peltate (arrow heads) trichomes are clearly seen. (8) Transverse section of calyx and corolla. On the abaxial surface of the corolla, the pelate trichomes are very abundant. On the adaxial surface the trichomes are non-glandular and unbranched.
Table 1. Composition of the essential oils of Teucrium capitatum from Portugal

\begin{tabular}{|c|c|c|c|c|c|}
\hline \multirow[b]{2}{*}{$\mathrm{RI}$ * Compound } & \multicolumn{5}{|c|}{$\%$ in samples } \\
\hline & 1 & 2 & 3 & 4 & 5 \\
\hline $923 \alpha$-Thujene & 0.2 & 1.5 & - & - & 0.2 \\
\hline $930 \alpha$-Pinene & 0.9 & 7.7 & 0.6 & 0.7 & 2.9 \\
\hline 941 Camphene & - & 0.3 & - & $\mathrm{t}$ & - \\
\hline 942 Verbenene & - & 0.2 & - & $\mathrm{t}$ & $\mathrm{t}$ \\
\hline 959 Oct-1-en-3-ol & 0.3 & 0.6 & 0.4 & 0.5 & 0.3 \\
\hline 964 Sabinene & 2.1 & 11.2 & 1.3 & 1.1 & 3.1 \\
\hline $970 \beta$-Pinene & 2.6 & 10.3 & 1.3 & 1.9 & 5.0 \\
\hline 981 Myrcene & 1.1 & 3.5 & 1.3 & 0.8 & 2.2 \\
\hline $1010 \alpha$-Terpinene & 0.3 & $\mathrm{t}$ & 0.1 & 0.1 & 0.3 \\
\hline $1012 p$-Cymene & 0.9 & 2.8 & 0.9 & 1.6 & 1.0 \\
\hline $1020 \beta$-Phellandrene & 0.4 & 0.7 & 0.2 & 0.3 & - \\
\hline 1020 1,8-Cineole & - & - & - & - & 1.0 \\
\hline 1020 Limonene & 1.0 & 3.1 & 0.7 & 0.6 & 1.2 \\
\hline $1025 \mathrm{Z}-\beta$-Ocimene & 0.1 & 0.1 & $\mathrm{t}$ & $\mathrm{t}$ & - \\
\hline $1036 E$ - $\beta$-Ocimene & 0.2 & 0.3 & $\mathrm{t}$ & $\mathrm{t}$ & 0.2 \\
\hline $1047 \gamma$-Terpinene & 1.0 & 1.7 & 0.6 & 0.3 & 0.7 \\
\hline $1051 \mathrm{Z}$-Sabinene hydrate & - & - & 0.3 & - & - \\
\hline 1056 Z-Linalool oxide & 0.1 & - & 0.2 & - & - \\
\hline $1066 E$-Linalool oxide & 0.2 & - & - & - & - \\
\hline 1066 2,5-Dimethylstyrene & - & 0.2 & - & $\mathrm{t}$ & - \\
\hline 1066 Fenchone & - & 0.1 & 0.6 & - & - \\
\hline 1079 Terpinolene & 0.4 & 0.5 & 0.3 & 0.2 & 0.2 \\
\hline 1081 Linalool & 1.5 & 1.1 & 1.5 & 0.6 & 0.8 \\
\hline 1081 Nonanal & - & - & - & - & 0.4 \\
\hline $1089 \beta$-Thujone & 0.1 & - & 0.3 & $\mathrm{t}$ & - \\
\hline $1104 \alpha$-Campholenal & 1.3 & 0.3 & 1.3 & $\mathrm{t}$ & 0.1 \\
\hline 1105 Nopinone & - & - & - & - & 0.3 \\
\hline 1106 cis-p-Menth-2-en-1-ol & - & 0.6 & - & - & - \\
\hline 1121 Camphor & - & 0.1 & - & - & 0.1 \\
\hline 1122 E-Pinocarveol & 2.2 & 1.3 & 2.4 & 1.8 & 0.8 \\
\hline $1125 \mathrm{Z}$-Verbenol & 2.5 & 1.1 & 3.5 & - & - \\
\hline 1126 Sabina ketone & - & - & - & 2.1 & - \\
\hline $1129 E$ E-Verbenol & - & - & - & - & 0.2 \\
\hline 1129 trans- $p$-Menth-2-en-ol & - & - & - & - & 0.4 \\
\hline 1135 Pinocarvone & 0.5 & 0.6 & 0.9 & 0.6 & 0.3 \\
\hline 1139 Isomenthone & 7.7 & - & - & - & - \\
\hline $1141 p$-Menth-1,5-dien-8-ol & - & - & - & - & 0.3 \\
\hline 1144 Borneol & 0.6 & 1.0 & 0.8 & 1.1 & 0.4 \\
\hline $1158 p$-Cymene-8-ol & 0.4 & 0.2 & 0.5 & 0.9 & 0.1 \\
\hline 1158 Terpineol-4 & 3.5 & 2.4 & 2.6 & 3.0 & 1.4 \\
\hline 1165 Menthol & 2.1 & - & - & - & - \\
\hline 1165 Myrtenal & 1.3 & 0.8 & 0.6 & 1.4 & 0.5 \\
\hline $1169 \alpha$-Terpineol & 0.3 & 0.3 & 0.4 & 0.7 & 0.3 \\
\hline 1176 Verbenone & - & - & - & - & 0.2 \\
\hline 1176 Myrtenol & 2.3 & 0.8 & 2.0 & 1.3 & 0.4 \\
\hline 1192 E-Carveol & - & - & - & - & 0.1 \\
\hline 1209 Cuminaldehyde & 0.7 & 0.5 & 0.9 & 0.9 & 0.3 \\
\hline 1211 Pulegone & 1.4 & - & - & - & - \\
\hline 1212 Carvone & 0.5 & - & $\mathrm{t}$ & - & - \\
\hline 1223 Piperitone & 0.1 & - & - & - & - \\
\hline 1233 Geraniol & - & - & - & 0.3 & - \\
\hline 1256 E-Anethol & 0.3 & - & - & - & - \\
\hline 1260 Cuminic alcohol & 0.3 & - & 0.4 & 1.4 & - \\
\hline 1266 Bornyl acetate & 0.6 & - & 0.4 & - & 0.2 \\
\hline 1267 Thymol & - & 2.3 & - & 1.5 & 0.1 \\
\hline 1272 Carvacrol & 0.4 & 0.4 & $\mathrm{t}$ & 0.9 & 3.0 \\
\hline 1301 Myrtenyl acetate & 0.9 & - & - & - & 0.5 \\
\hline $1329 \alpha$-Terpinyl acetate & 1.3 & 0.9 & - & 1.3 & 0.7 \\
\hline $1342 \alpha$-Cubebene & 0.3 & 0.2 & 0.5 & 0.7 & 0.6 \\
\hline 1360 Cyclosativene & - & 0.4 & - & 1.1 & 0.3 \\
\hline $1369 \alpha$-Copaene & 0.3 & 0.6 & 1.3 & 1.2 & 1.3 \\
\hline $1376 \beta$-Bourbonene & 0.3 & - & - & - & 0.1 \\
\hline $1381 \beta$-Cubebene & 1.1 & 1.2 & 3.3 & 2.8 & 3.0 \\
\hline $1381 \beta$-Elemene & - & - & - & - & 0.2 \\
\hline $1402 \alpha$-Gurjunene & - & $\mathrm{t}$ & 0.5 & 0.4 & 0.4 \\
\hline 1409 E-Caryophyllene & 4.8 & 3.8 & 3.3 & 5.4 & 4.6 \\
\hline $1418 Z$ Z- $\alpha$-Bergamotene & - & - & - & 0.1 & - \\
\hline
\end{tabular}


Table 1. (Continued)

\begin{tabular}{|c|c|c|c|c|c|}
\hline \multirow[b]{2}{*}{ RI* Compound } & \multicolumn{5}{|c|}{$\%$ in samples } \\
\hline & 1 & 2 & 3 & 4 & 5 \\
\hline $1428 E$ - $\alpha$-Bergamotene & - & 0.6 & - & - & 0.3 \\
\hline $1428 \alpha$-Guaiene & 0.5 & - & 0.5 & - & - \\
\hline $1441 \alpha$-Humulene & 2.0 & 1.8 & 2.0 & 2.7 & 2.6 \\
\hline $1446 E$ - $\beta$-Farnesene & 0.6 & 0.6 & - & - & 0.1 \\
\hline 1448 allo-Aromadendrene & - & - & 0.5 & 0.5 & 0.1 \\
\hline $1466 \gamma$-Muurolene & - & - & 0.6 & - & $\mathrm{t}$ \\
\hline $1466 \gamma$-Gurjunene & - & - & - & - & 0.4 \\
\hline 1467 Germacrene D & 3.5 & 3.6 & - & 3.5 & 2.6 \\
\hline $1479 \alpha$-Selinene & - & - & - & - & 0.6 \\
\hline 1482 Bicyclogermacrene & 1.9 & 1.9 & - & 0.7 & 2.3 \\
\hline $1487 \alpha$-Muurolene & 0.6 & - & 0.4 & 0.8 & 0.6 \\
\hline $1498 \gamma$-Cadinene & 1.3 & - & 5.5 & 1.1 & 1.9 \\
\hline $1497 \beta$-Bisabolene & - & - & - & 0.8 & - \\
\hline 1502 Z-Calamelene & - & - & - & 0.3 & 0.2 \\
\hline 1503 7-epi- $\alpha$-Selinene & 0.8 & 1.9 & - & - & - \\
\hline $1508 \delta$-Cadinene & 3.0 & 4.9 & 3.7 & 7.5 & 9.8 \\
\hline 1517 Cadina-1,4-diene & - & - & - & - & 0.2 \\
\hline $1521 \alpha$-Cadinene & 0.8 & 0.4 & - & 0.8 & 一 \\
\hline 1526 Elemol & 1.8 & - & - & 1.8 & - \\
\hline $1531 \alpha$-Bisabolene & - & 0.6 & - & - & 0.4 \\
\hline 1540 Germacrene B & 0.5 & 0.4 & - & - & 0.5 \\
\hline 1542 E-Nerolidol & - & 0.6 & 1.7 & 0.9 & 0.3 \\
\hline 1552 Spathulenol & 1.1 & - & - & 2.5 & 0.5 \\
\hline 1554 Germacrene-1(10),5-dien-4-ol & - & - & - & - & 1.3 \\
\hline 1558 Caryophyllene oxide & 1.4 & 0.6 & 3.1 & 1.4 & 0.8 \\
\hline 1568 Viridiflorol & 0.3 & - & - & 1.1 & - \\
\hline $1596 \delta$-Selinene & 1.9 & 0.7 & 0.8 & 2.0 & 0.4 \\
\hline $1606 \gamma$-Eudesmol & - & - & - & 2.1 & - \\
\hline 1616 T-Cadinol & 5.5 & 1.6 & 24.1 & 3.0 & 3.2 \\
\hline $1616 \alpha$-Muurolol & - & - & - & - & 6.0 \\
\hline $1620 \beta$-Eudesmol & 0.0 & 0.4 & - & 2.7 & - \\
\hline 1628 T-Muurorol & 1.5 & 1.2 & 1.0 & 1.7 & - \\
\hline $1628 \alpha$-Cadinol & 3.2 & 1.6 & 9.8 & 4.2 & 4.6 \\
\hline 1632 7-epi- $\alpha$-Eudesmol & - & - & - & 2.0 & - \\
\hline $1659 \alpha$-Bisabolol & - & 1.5 & - & - & 3.7 \\
\hline 2098 Phytol & 0.1 & - & - & 0.2 & 一 \\
\hline Monoterpene hydrocarbons & 11.2 & 43.9 & 7.3 & 7.6 & 17.0 \\
\hline Oxygen-containing monoterpenes & 33.0 & 14.9 & 19.8 & 19.7 & 12.5 \\
\hline Sesquiterpene hydrocarbons & 24.3 & 23.2 & 23.0 & 32.2 & 33.2 \\
\hline Oxygen-containing sesquiterpenes & 14.9 & 7.5 & 39.7 & 23.4 & 20.4 \\
\hline Others & 0.4 & 1.2 & 0.4 & 0.8 & 1.0 \\
\hline Total identified & 83.8 & 90.7 & 90.0 & 83.7 & 84.1 \\
\hline
\end{tabular}

* Compounds listed in order of their elution from the polymethylsiloxane column. $t<0.05 \%$.

The chemical composition of our oil sample 2 (Serra do Sicó, Rabaçal) is quite similar to that reported for T. polium ssp. capitatum grown on Sierra Helada, Spain, which possessed considerable amounts of $\alpha$-pinene $(11.6 \%), \beta$-pinene $(18.1 \%)$ and sabinene $(13.0 \%){ }^{7}$

Our results showed important differences among the essential oils obtained from plants collected at the same developmental stage, even among those from the same collection sites or very close localities with similar ecological and edaphic features. This fact indicates that the chemical polymorphism of the volatile oil of $T$. capitatum might be due, in part, to genetic characters.

Acknowledgements - We thank Professor Dr Jorge Paiva and Dr Paulo Rosa (University of Coimbra Botanical Garden) for providing some plant material and for their invaluable help in plant classification.

\section{References}

1. Devesa JA. In Flora Vasc. Andalucía Occidental, vol 2, Teucrium, Valdés B, Talavera S, Fernandéz-Galiano E (eds). Ketres: Barcelona, 1987; 458-469.

2. Oualidi JE, Verneau O, Puech S, Dubuisson JY. Pl. Syst. Evol. 1999; 215: 49-70.

3. Wassel GM, Ahmed SS. Pharmazie 1974; 29: 351-352.

4. Pérez-Alonso MJ, Velasco-Negueruela A, López-Sáez JA. J. Essent. Oil. Res. 1993; 5: 397-402.

5. Cakir A, Duru ME, Harmandar M, Ciriminna R, Passannanti S. J. Essent. Oil Res. 1998; 10: 113-115.

6. Eikani MJ, Goodarznia I, Mirza M. J. Essent. Oil Res. 1999; 11: 470-472.

7. Morera Marante MP. Composición de los aceites esenciales de plantas del género Teucrium PhD Thesis, Complutense University, Madrid, 1981.

8. Ganter P, Jolles G. Histochimie Normal et Pathologique, vol I, II. Gauthier-Villars: Paris, 1969.

9. Cain Aj. Qu. J. Micr. Sci. 1947; 88: 383-392.

10. Council of Europe. European Pharmacopoeia, 3rd edn. Strasbourg, 1997: 121-122.

11. Adams RP. Identification of Essential Oil Components by Gas Chromatography/Mass Spectroscopy. Allured: Carol Stream, IL, 1995.

12. Joulain D, König WA. The Atlas of Spectral Data of Sesquiterpene Hydrocarbons. E.B.-Verlag: Hamburg, 1998.

13. Servettaz O, Bini Maleci L, Pinetti A. Pl. Syst. Evol. 1992; 179: 129-139.

14. Antunes T, Sevinate-Pinto I, Figueiredo AC et al. Acta Bot. Gallica 1997; 144: 363-369.

15. Werker E. Flavour Fragr. J. 1993; 8: 249-255.

16. Cantino PD. J. Arnold Arboretum 1990; 71: 323-370.

17. Antunes T, Sevinate-Pinto I, Barroso JG et al. Bol. Мuseu Mun. Funchal (História Natural) 1995; 4: 21-27.

18. Cavaleiro C, Salgueiro LR, Antunes T, Sevinate-Pinto I, Barroso JG. Flavour Fragr. J. 2002; 17: 287-291.

19. Fanh A. New Phytol. 1988; 108: 229-257.

20. Bisio A, Corallo A, Gastaldo P et al. Ann. Bot. 1999; 83: 441452. 